\title{
Novel Senescent Regulatory T-Cell Subset with Impaired Suppressive Function in Rheumatoid Arthritis
}

\begin{abstract}
Johannes Fessler', Andrea Raicht', Rusmir Husic', Anja Ficjan', Christine Schwarz², Christina Duftner ${ }^{3}$, Wolfgang Schwinger ${ }^{2}$, Winfried B. Graninger ${ }^{1}$, Martin H. Stradner ${ }^{1 *}$ and Christian Dejaco ${ }^{1,4}$

${ }^{1}$ Department of Rheumatology and Immunology, Medical University of Graz, Graz, Austria, ${ }^{2}$ Department of Pediatric Hemato-Oncology, Medical University of Graz, Graz, Austria, ${ }^{3}$ Department of Internal Medicine VI, Innsbruck Medical University, Innsbruck, Austria, ${ }^{4}$ Rheumatology Service, South Tyrolian Health Trust, Hospital Bruneck, Bruneck, Italy
\end{abstract}

OPEN ACCESS

Edited by: Wanjun Chen, National Institutes of Health, USA

Reviewed by: Akihiko Yoshimura, Keio University, Japan Paula M. Oliver, University of Pennsylvania, USA

${ }^{*}$ Correspondence: Martin H. Stradner martin.stradner@medunigraz.at

Specialty section: This article was submitted to $T$ Cell Biology, a section of the journal Frontiers in Immunology

Received: 13 December 2016 Accepted: 03 March 2017 Published: 20 March 2017

Citation:

Fessler J, Raicht A, Husic R, Ficjan A, Schwarz C, Duftner C, Schwinger W, Graninger WB, Stradner MH and Dejaco C (2017) Novel Senescent

Regulatory T-Cell Subset with Impaired Suppressive Function in Rheumatoid Arthritis.

Front. Immunol. 8:300. doi: 10.3389/fimmu.2017.00300
Objective: Premature senescence of lymphocytes is a hallmark of inflammatory rheumatic diseases such as rheumatoid arthritis (RA). Early T-cell aging affects conventional T-cells but is presumably not limited to this cell population; rather it might also occur in the regulatory T-cells (Tregs) compartment. In RA, Tregs fail to halt aberrant immune reactions and disease progression. Whether this is associated with early Treg senescence leading to phenotypic and functional changes of this subset is elusive so far.

Methods: Eighty-four RA patients and 75 healthy controls were prospectively enrolled into the study. Flow cytometry, magnetic-associated cell sorting, and cell culture experiments were performed for phenotypic and functional analyses of Treg subsets. T-cell receptor excision circle (TREC) levels and telomere lengths were determined using RT-PCR.

Results: In this paper, we describe the novel CD4+FoxP3+CD28- T-cell subset (CD28Treg-like cells) in RA patients revealing features of both Tregs and senescent T-cells: Treg surface/intracellular markers such as CD25, CTLA-4, and PD-1 as well as FOXP3 were all expressed by CD28- Treg-like cells, and they yielded signs of premature senescence including reduced TREC levels and an accumulation of $\gamma \mathrm{H} 2 \mathrm{AX}$. CD28- Treg-like could be generated in vitro by stimulation of $\left(\mathrm{CD}_{28}{ }^{+}\right)$Tregs with TNF- $\alpha . \mathrm{CD}^{2} 8^{-}$Treg-like cells insufficiently suppressed the proliferation of effector T-cells and yielded a pro-inflammatory cytokine profile.

Conclusion: In conclusion, we describe a novel T-cell subset with features of Tregs and senescent non-Tregs. These cells may be linked to an aberrant balance between regulatory and effector functions in RA.

Keywords: regulatory T cells, rheumatoid arthritis, immunosenescence, aging, premature, autoimmunity 


\section{INTRODUCTION}

Regulatory T-cells (Tregs) were identified as sentinels of the immune response keeping aberrant immune reactions in track and preventing autoimmunity. The current understanding of the pathogenesis of rheumatoid arthritis (RA) is that this equilibrium is disturbed, in part due to quantitative and/or qualitative defects of Tregs [reviewed in Ref. (1)]. Currently available data on this topic, however, are contradictory in part: Lawson et al., for example, observed a reduced prevalence of circulating $\mathrm{CD} 4{ }^{+} \mathrm{CD} 25^{\text {high }}$ Tregs in patients with early active RA (2), whereas others were unable to reproduce this finding $(3,4)$. Ehrenstein et al. reported a defect of Tregs in the suppression of pro-inflammatory cytokine production (5), and Nie et al. showed a reduced suppression of proliferating effector cells by Tregs that was TNF dependent (6). Other groups, however, reported that the suppressive function of Tregs in RA is normal $(3,4,7)$.

These discrepancies are potentially linked to the fact that Tregs are not a single cell population but rather comprise developmentally and functionally distinct subsets that may vary among RA populations. Similar to non-Tregs are educated in the thymus and are then released in a "naive-like" $\mathrm{CD} 25^{+} \mathrm{CD} 45 \mathrm{RA}^{+}$ phenotype into periphery $(8,9)$. Upon antigen contact, Tregs differentiate into a "memory-like" $\mathrm{CD} 25^{\mathrm{hi}} \mathrm{CD} 45 \mathrm{RO}^{+}$phenotype (10). Memory-like Tregs have a lower proliferative capacity and different homing behavior compared to naive-like Tregs and yield shorter telomeres as well as a lower content of T-cell receptor excision circles, an extrachromosomal DNA byproducts of T-cell receptor (TCR) rearrangement that is diluted by peripheral $\mathrm{T}$-cell division, indicating a longer replicative history.

During aging, the thymus undergoes progressive involution leading to an elevated homeostatic pressure on peripheral T-cells $(11,12)$. Proliferation of peripheral T-cells compensates for dwindling thymic output until telomeres are contracted to levels known as the "Hayflick limit." At this stage, non-Tregs undergo senescence-associated phenotypical and functional changes such as downregulation of CD28. Due to the fact that Tregs display even shorter telomeres than non-Tregs, it is conceivable that Tregs proliferating in periphery reach the "Hayflick limit" even earlier (13). Impaired Treg homeostasis and function might then result in an increased risk of immune-mediated disorders.

In RA, senescence of non-Treg including the accumulation of $\mathrm{CD} 28^{-} \mathrm{CD} 4^{+} \mathrm{T}$-cells has been observed even in young individuals $(14,15)$. CD28- T-cells from RA patients are pro-inflammatory and cytotoxic, and a high prevalence of this cellular subset has been associated with higher disease severity and cardiovascular events $(14,16-18)$. Whether in RA, premature senescence including the loss of CD28 molecule also affects Tregs has not been investigated so far. From a mouse model with a conditional CD28 knockout in Tregs we know that the loss of this co-stimulatory molecule severely compromises Treg function leading to the development of autoimmunity (19).

This study aims at the identification and characterization of $\mathrm{CD}^{+}{ }^{+} \mathrm{CD} 28^{-}{ }^{-}$oxP3 $^{+} \mathrm{T}$-cells in patients with RA.

\section{PATIENTS AND METHODS}

\section{Study Population}

This was a prospective study of consecutive patients with a final diagnosis of RA based on the 2010 ACR/EULAR criteria (20) as well as age- and sex-matched healthy individuals (HC). Detailed medical history including disease duration, prior, and current treatments was obtained from each patient. Each patient also underwent full clinical assessment with determination of disease activity according to the simplified disease activity index (SDAI) (21) and the disease activity score 28 (22). Whenever available, synovial fluid samples were obtained from patients undergoing routine joint aspiration.

\section{Peripheral Blood Mononuclear Cells (PBMCs) and Cell Culture}

Peripheral venous blood or synovial fluid was drawn from each individual, and PBMCs were isolated by Histopaque density gradient centrifugation. The total cell number was determined by a Beckmann Coulter. Cells were cultured at $1 \times 10^{6} \mathrm{cells} / \mathrm{ml}$ in RPMI 1640 containing 10\% fetal calf serum, $2 \mathrm{mM} \mathrm{L-glutamine,}$ $100 \mathrm{U} / \mathrm{ml}$ penicillin, and $100 \mu \mathrm{g} / \mathrm{ml}$ streptomycin in the presence of $20 \mathrm{U} / \mathrm{ml}$ human recombinant IL-2 (SIGMA, Vienna, Austria) and initial stimulation with $10 \mu \mathrm{g} / \mathrm{ml}$ plate-bound anti-CD3 Ab.

\section{Flow Cytometry}

Surface and intracellular staining of freshly isolated PBMCs was performed using appropriate combinations of antibodies for detection of CD3, CD4, CD28, CD25, CD127, FoxP3, CTLA-4, IL-10, TNF- $\alpha$, Th1-type cytokines IL-2 and IFN- $\gamma$, Th2-type cytokine IL-4 and Th17-type cytokine IL-17 (all Becton Dickinson, San Diego, CA, USA), and $\gamma \mathrm{H} 2 \mathrm{AX}$ (Cell Signaling, Danvers, MA, USA). Surface staining for $20 \mathrm{~min}$ was followed by permeabilization for $30 \mathrm{~min}$ and intracellular staining for $30 \mathrm{~min}$ according to a routine protocol. Golgi transport was inhibited by brefeldin $\mathrm{A}(10 \mathrm{ng} / \mathrm{ml})$ or monensin $(10 \mathrm{ng} / \mathrm{ml}) 4 \mathrm{~h}$ prior to cytokine staining. Appropriate isotype controls were used. Stained cells were analyzed on a FACS Canto II (Becton Dickinson). Data are analyzed with DIVA software and FlowJo.

\section{Isolation of T-Cell Subsets}

For functional assays, $\mathrm{CD} 4^{+} \mathrm{T}$-cells were isolated by positive selection of PBMCs labeled with magnetic-bead conjugated antihuman CD4 mAbs using MACS MultiSort Kit and autoMACSPro according to manufacturer's instructions (Miltenyi). Purified $\mathrm{CD} 4^{+} \mathrm{T}$-cells were then separated into the $\mathrm{CD} 28^{+} \mathrm{CD} 25^{+} \mathrm{CD} 127^{\mathrm{dim}}$ (conventional regulatory), $\mathrm{CD} 28^{+} \mathrm{CD} 25^{-}$(conventional nonregulatory), and $\mathrm{CD} 28^{-} \mathrm{CD} 25^{+} \mathrm{CD} 127^{\mathrm{dim}}$ (senescent Treg-like) fractions by another sorting step using FACS technology (FACS Aria). In order to obtain sufficient numbers of RA Tregs, preenrichment of PBMCs was necessary and resulted in upregulation of CD25. Therefore, isolation of Treg subsets was based on CD25 positivity as well as absence of CD127. For CD28 downregulation experiments, Tregs were isolated using $\mathrm{CD} 4^{+} \mathrm{CD} 25^{+} \mathrm{CD} 127^{\mathrm{dim} /-}$ Reg. T Cell isolation Kit II (Miltenyi) and autoMACSPro. For validation, flow cytometry was then performed to determine purity ( $>90 \%$ ) of selected cells. 


\section{Determination of TCR Diversity}

RNA from enriched subsets was extracted using RNeasy Protect Mini Kit (Qiagen, Germantown, MD, USA) according to the manufacturer instructions. RNA was used for reverse transcription with First Strand cDNA Synthesis Kit for RT-PCR AMV (Roche) according to the manufacturer regulations. cDNA was diluted 1:5 for PCR using AmpliTaq Gold ${ }^{\mathrm{TM}}$ DNA Polymerase (Applied Biosystems), $1 \times$ PCR Gold Buffer (Applied Biosystems), $2.5 \mathrm{mM}$ $\mathrm{MgCl}_{2}$ (Applied Biosystems), $0.4 \mathrm{mM}$ dNTP Polymerization Mix (GE Healthcare), $0.5 \mu \mathrm{M}$ TCR C $\beta$ 5'FAM labeled primer (Ingenetix, Vienna, Austria), and $0.5 \mu \mathrm{M}$ unlabeled TCR V $\beta$ primers (Ingenetix) according to Hingorani et al. (23). Primer sequences are listed in Table S2 in Supplementary Material. Cycle conditions were a denaturation step at $94^{\circ} \mathrm{C}$ for $6 \mathrm{~min}, 35 \mathrm{cycles}$ of $94^{\circ} \mathrm{C}$ for $1 \mathrm{~min}, 59^{\circ} \mathrm{C}$ for $1 \mathrm{~min}$, and $72^{\circ} \mathrm{C}$ for $1 \mathrm{~min}$, a final annealing step at $72^{\circ} \mathrm{C}$ for $7 \mathrm{~min}$. After amplification, the PCR product was supplemented with GeneSCan ${ }^{\mathrm{TM}_{-}} 500$ TAMRA $^{\mathrm{TM}}$ Size Standard (Applied Biosystems) and HI-DI Formamide (Applied Biosystems). Electrophoresis was performed with ABI Prism 310 Genetic Analyzer (Applied Biosystems), and 310 Data Collection Software. Analysis was done by GeneScan ${ }^{\circledR}$ Software (Applied Biosystems). Calculations included peak count (Complexity score) and single peak area in percent of whole peak area.

\section{Senescence-Associated $\beta$-Galactosidase Assay}

Freshly isolated PBMCs were treated with the "Quantitative Cellular Senescence Assay Kit" (Cell Biolabs) according to the manufacturer's instructions. Afterward, a surface and intracellular staining of cells was performed as described above.

\section{Determination of Telomere Length}

DNA from enriched subsets was extracted using QIAamp DNA Blood Mini Kit (Qiagen, Germantown, MD, USA) according to the manufacturer instructions. Telomere lengths were measured using DNA from PBMCs as well as T-cell subsets by quantitative real-time PCR analysis and LightCycler FastStart DNA Master SYBR Green I (Roche, Vienna, Austria) as previously described (24).

\section{Suppression Assay}

$\mathrm{CD}^{+} \mathrm{T}$-cells were isolated always from the same healthy donor (JF) since RA effector cells were reported to be resistant to Tregmediated suppression (5). Cells were incubated with CellTrace Violet (Life Technologies) and cultured in the presence or absence of $\mathrm{CD} 28^{+} \mathrm{CD} 25^{+} \mathrm{CD} 127^{\mathrm{dim}}$ or $\mathrm{CD} 28^{-} \mathrm{CD} 25^{+} \mathrm{CD} 127^{\mathrm{dim}} \mathrm{RA}$ T-cells at a 1:1 ratio. Autologous $\mathrm{CD} 28^{+} \mathrm{CD} 25^{+} \mathrm{CD} 127^{\mathrm{dim}}$ served as a control. Cells were stimulated by adding $10 \mu \mathrm{g} / \mathrm{ml}$ anti-CD3 Ab and incubated at $37^{\circ} \mathrm{C}$ for 3 days and analyzed by flow cytometry. To elucidate the impact of TNF- $\alpha$ and IFN- $\gamma$ on the suppressive potential of different subsets, we added neutralizing antibodies (R\&D systems) at $10 \mu \mathrm{g} / \mathrm{ml}$. A normal goat IgG control was also added at the start of culture accounting for any non-specific changes.

\section{Proliferation Assay}

For all experiments, freshly purified PBMCs were resuspended in PBS at 5-10 $\times 10^{6}$ cells $/ \mathrm{ml}$ and incubated with CFSE $(1 \mu \mathrm{M})$ for
$7 \mathrm{~min}$ at $37^{\circ} \mathrm{C}$. Cells were washed three times and resuspended in culture medium. Cells were stimulated with plate-bound anti-CD3 $(10 \mu \mathrm{g} / \mathrm{ml}, 18 \mathrm{~h})$ or PHA $(1 \mu \mathrm{g} / \mathrm{ml})$ and cultured for $72 \mathrm{~h}$. Afterward cells were stained as described in Section "Flow Cytometry."

\section{Apoptosis Assay}

Freshly isolated PBMCs were stimulated with plate-bound anti-CD3 $(10 \mu \mathrm{g} / \mathrm{ml})$ or PHA $(1 \mu \mathrm{g} / \mathrm{ml})$ and cultured for $18 \mathrm{~h}$. Afterward cells were harvested and stained for Annexin $\mathrm{V}$ and viability dye (ebioscience, San Diego, CA, USA) as well as surface markers according to the manufacturer's protocol. Annexin $\mathrm{V}^{+}$cells represent apoptotic cells, viability dye $\mathrm{e}^{+}$cells represent necrotic cells, and double positive cells represent late apoptotic cells.

\section{CD28 Downregulation Experiments}

$\mathrm{CD} 4^{+} \mathrm{CD} 25^{+} \mathrm{CD} 127^{\mathrm{dim} /-}$ Tregs were isolated using AutoMACS (Miltenyi, Bergisch Gladbach, Germany) according to the manufacturer's instructions. Subsequently, cells were cultured as described (25): in brief, $1 \times 10^{5}$ cells/ml were cultured in a 96-well plate with culture media and anti-CD3/CD28 MoAbcoated microbeads (Life Sciences, Waltham, MA, USA) at a 4:1 bead-to-cell ratio and were stimulated with $200 \mathrm{U} / \mathrm{ml}$ IL-2, with or without $100 \mathrm{ng} / \mathrm{ml} \mathrm{TNF-} \alpha$ (SIGMA) or IL-15 (Life Sciences). After 6 days of cultivation, the cells were harvested, washed, and then cultured in the presence of $20 \mathrm{U} / \mathrm{ml} \mathrm{IL}-2$ for two more days. Thereafter, the expanded Tregs were restimulated for another 6 days with anti-CD3/CD28 MoAb-coated microbeads at a beadto-cell ratio of 2:1 and $200 \mathrm{U} / \mathrm{ml}$ IL-2. Cells were analyzed after each expansion phase.

\section{Statistical Analysis}

All statistical analyses were performed using the SPSS program, version 23 (Chicago, IL, USA). In case of a normal distribution (tested with the Kolmogorov-Smirnov test) of the continuous variables, the mean and SD are shown, and we used the two-sided Student's $t$-test (comparison of two groups) or ANOVA (comparison of three or more groups) for comparisons. In case of a nonparametric distribution, the median and range are shown, and we used the Mann-Whitney $U$ and the Kruskal-Wallis tests to assess differences between groups. Correlation between variables was evaluated by the Spearman's rank correlation coefficient. Paired data were compared with the Wilcoxon test.

\section{Study Approval}

This study was approved by the Institutional Review Board of the Medical University Graz, and written informed consent was obtained from each individual prior to inclusion in the study.

\section{RESULTS}

\section{$\mathrm{CD4}^{+}{ }^{\mathrm{CD} 28}-\mathrm{FoxP}^{+}{ }^{+}$-Cells Have a Treg- Like Phenotype and Are Prevalent in RA}

We know that in RA, (1) a proportion of T-cells lack the costimulatory molecule CD28, (2) the loss of CD28 reflects early 
T-cell senescence and is partially caused by pro-inflammatory stimuli, and (3) Tregs undergo a similar development to nonTregs from a naïve-like to a memory-like status. We therefore investigated whether expression of CD28 is reduced on FoxP3 ${ }^{+}$ T-cells (which is the most specific marker for Tregs) from RA patients.

In RA patients but not in controls, we observed a FoxP3 ${ }^{+}$ T-cell subset lacking the expression of CD28. The prevalence of circulating $\mathrm{CD}^{+} \mathrm{CD} 28^{-}{ }^{-}{ }^{-} \mathrm{xP}^{+}{ }^{+} \mathrm{T}$-cells was higher in $\mathrm{RA}$ patients compared to healthy individuals $\left[0.7 \%\right.$ of total $\mathrm{CD} 4^{+}$ (range $0-19.2)$ vs. $0.2 \%(0-17) ; p=0.029$; Figures $\mathbf{1 A}, \mathbf{B}]$, whereas the frequency of $\mathrm{CD} 4{ }^{+} \mathrm{CD} 28^{+} \mathrm{FoxP} 3{ }^{+} \mathrm{CD} 25^{+}$Tregs was equal in both groups [ $5 \%$ of total $\mathrm{CD}^{+}(3.2-7.3)$ vs. $4.9 \%$ (3.29.5); $p=0.988$; Figure 1C]. The intensity of FoxP3 expression was similar in CD28 ${ }^{-}$and $\mathrm{CD}^{2} 8^{+}$subsets (MFI: $601.8 \pm 200.4$ vs. $634.8 \pm 196.5, p>0.05$, Figures $2 A, B)$. In synovial fluid samples from RA patients, we noted that $3.8 \%(1.6-18.8)$ of $\mathrm{CD} 4^{+} \mathrm{FoxP}^{+}{ }^{+}$-cells were negative for $\mathrm{CD} 28(n=8$, data not shown).

Alongside FoxP3, CD25 and a low expression of CD127 are characteristic for Tregs $(26,27)$. CD4 ${ }^{+}$CD28-FoxP3 ${ }^{+}$T-cells were positive for CD25 and expressed low levels of CD127; both markers, however, were reduced relative to $\mathrm{CD} 4^{+} \mathrm{CD} 28^{+} \mathrm{FoxP}^{+}$ Tregs: CD25, MFI: 328 (199-2,068) vs. 1,998 (1,456-2,946); $p<0.001$; Figure 2C and CD127, MFI: 454 (111-905) vs. 1,206 (906-1,961); $p<0.001$; Figure 2D. CTLA-4, PD-1, and CD15s are other typical markers of Tregs, all of them were found on $\mathrm{CD}^{+}{ }^{+} \mathrm{CD} 28^{-} \mathrm{FoxP}^{+}$: CTLA-4 expression was similar in $\mathrm{CD}^{+}{ }^{+} \mathrm{CD} 28^{-} \mathrm{FoxP}^{+}{ }^{+} \mathrm{T}$-cells and $\mathrm{CD} 4^{+} \mathrm{CD} 28^{+} \mathrm{FoxP}^{+}$Tregs [MFI: 123.5 (103-350) vs. 122 (104-648); $p=0.499$; Figure 2E], whereas PD-1 was higher [MFI: 449.5 (167-811) vs. 258.5 (221-480); $p=0.017$; Figure 2F] and CD15s lower [MFI: 864.5 (647-914) vs. 1,102.5 (690-1,251); $p=0.028$; Figure 2G] in the former compared to the latter cell population. CCR6, another molecule normally expressed by Tregs was almost absent on $\mathrm{CD}^{+}{ }^{+} \mathrm{CD} 28^{-}{ }^{-}$-oxP $3{ }^{+} \mathrm{T}$-cells $\left[0.2 \%(0-7.5)\right.$ of $\mathrm{CD} 4^{+} \mathrm{CD} 28^{-}{ }^{-} \mathrm{FoxP}^{+}$ T-cells were positive for CCR6 ${ }^{+}$vs. $39.8 \%(28.9-55.2)$ of CD28 ${ }^{+}$ Tregs; $p=0.012$, Figure $2 \mathbf{H}$ ] (28).

Collectively, these analyses suggest that $\mathrm{CD} 4^{+} \mathrm{CD} 28^{-} \mathrm{FoxP}^{+}$ T-cells have a Treg-like phenotype.

\section{CD28- Treg-Like Cells Underwent Cellular Senescence}

To investigate whether the novel $\mathrm{CD}_{2} 8^{-}$Treg-like subset revealed signs of cellular senescence in addition to the loss of CD28, we undertook the following experiments: first, we tested the accumulation of $\gamma \mathrm{H} 2 \mathrm{AX}$ foci, which represent repair-proof double-strand breaks in DNA (29). Second, we performed TCR spectratyping because TCR diversity is known to diminish along with T-cell aging (30). Third, we tested the accumulation of senescence-associated $\beta$-galactosidase (SABG) another known biomarker of cellular senescence (31). Fourth, we measured the telomere length given that a shrinkage of telomeres is considered to indicate replicative senescence (32).


B
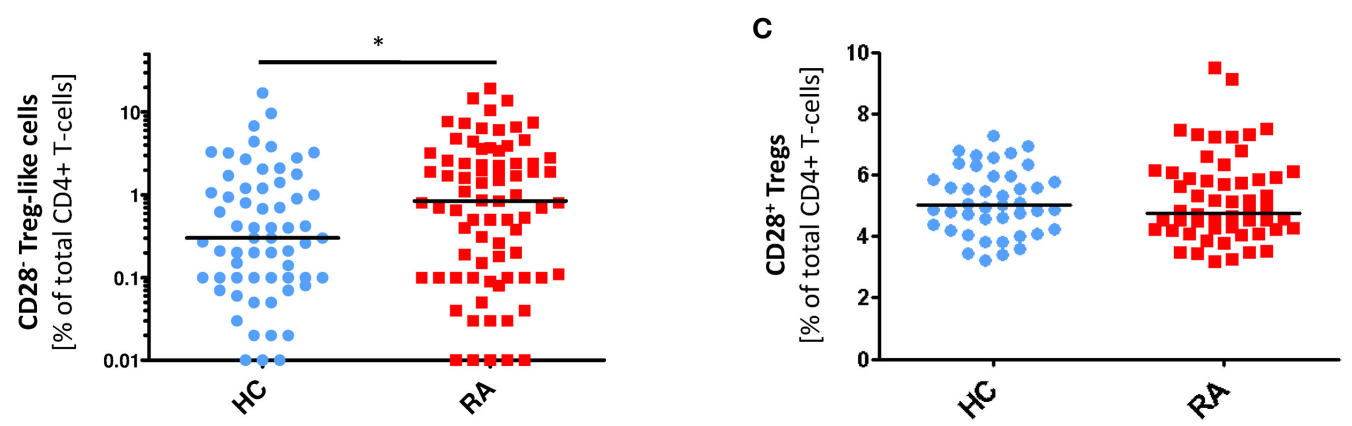

FIGURE 1 | CD28- regulatory T-cells (Tregs)-like cells are enriched in patients with rheumatoid arthritis (RA). Graphs show (A) representative dot plots of CD28- Treg-like cells (gated on CD4+FoxP3+ T-cells) of patients with RA $(n=84)$ and HC $(n=75)$ and statistical analysis as well as (B) prevalences of CD28- Treglike cells and (C) CD28+ Tregs of healthy controls ( $\mathrm{HC}$, blue) and RA patients (red); Mann-Whitney $U$ test and Student's $t$-test, respectively, were used to assess differences between groups. ${ }^{*} p \leq 0.05$. 


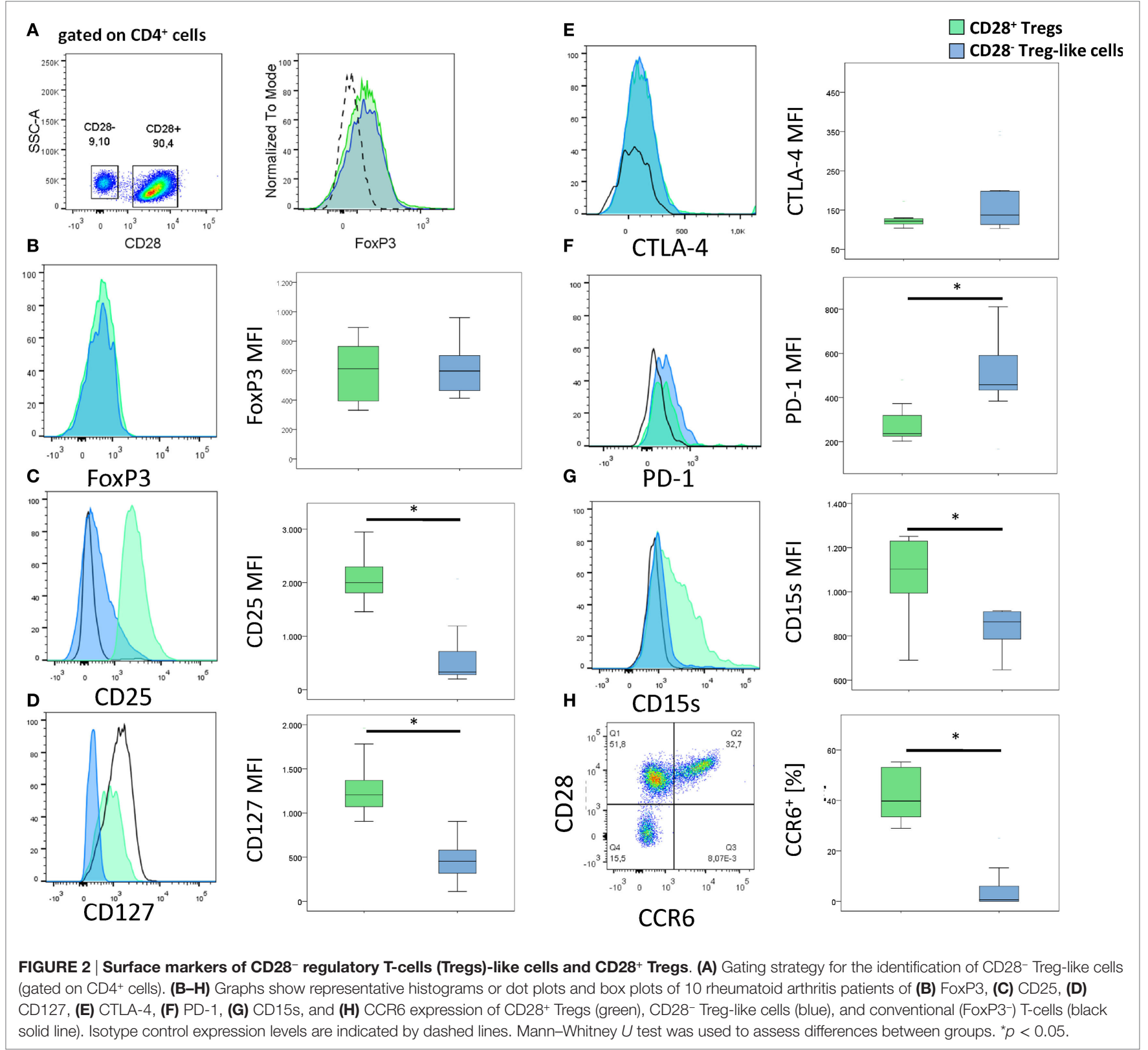

As depicted in Figure $3 \mathbf{A}, \mathrm{CD} 28^{-}$Treg-like cells showed higher $\gamma \mathrm{H} 2 \mathrm{AX}$ mean fluorescence intensity than CD28 ${ }^{+}$Tregs [MFI: 6,422 (2,952-258,589) vs. 4,875 (2,875-7,743), $p=0.046$ ]. Similarly, TCR diversity was reduced in CD28- Treg-like cells [84 (36-104)] compared to their CD28 ${ }^{+}$counterparts [115 (109-125); $p=0.037$; Figure 3B]. SABG expression, moreover, was likewise enhanced in CD28- Treg-like cells [MFI: 1,117 (671-1,263) vs. 499 (474-591); $p=0.043$; Figure 3C].

Interestingly, telomere length was similar in CD28- Treg-like cells [6.11 kbp (5.46-6.19)] and CD28 ${ }^{+}$Tregs [5.89 (5.6-6.17), $p=0.373$, Figure 3D]. From previous studies we know, however, that the telomere length of Tregs is reduced already (compared to non-Tregs), and a further shrinkage of telomeres is thus unlikely to occur (13).

\section{Association of CD28- Treg-Like Cells with Clinical Parameters of RA}

Clinical characteristics of RA patients and controls are depicted in Table S1 in Supplementary Material. Two (3.3\%), 8 (13.1), and 32 (52.5) out of the $61 \mathrm{RA}$ patients with available SDAI values had high, moderate, or low disease activity, respectively; 19 (31.1) patients were in clinical remission (33). Five (6\%) RA patients had early disease ( $\leq 2$ years' duration).

Frequencies of CD28- Treg-like cells (but not those of CD28 ${ }^{+}$Tregs) correlated with age in RA patients and controls (corr $_{\text {coeff }}=0.416, p<0.001$ and $\operatorname{corr}_{\text {coeff }}=0.557, p<0.001$, respectively; Figure S1A in Supplementary Material). Neither the prevalence of CD28- Treg-like cells nor those of CD28+ Tregs was linked with disease duration, acute phase reactants, clinical 


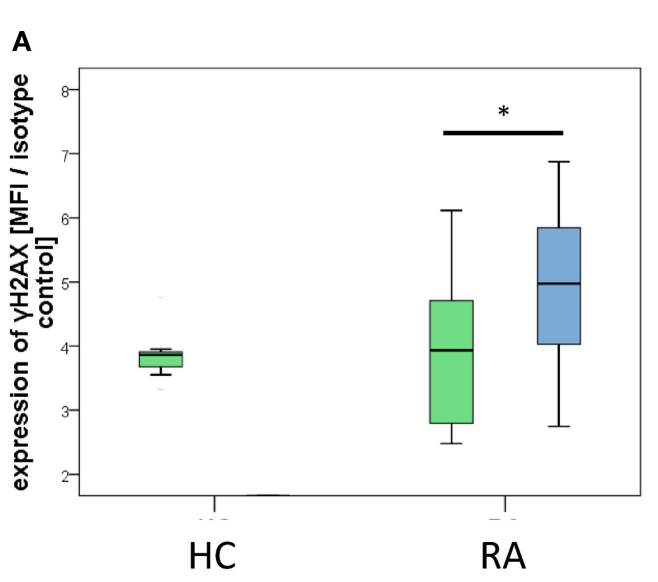

B

CD28+ ${ }^{+}$Tregs

CD28- Treg-like cells
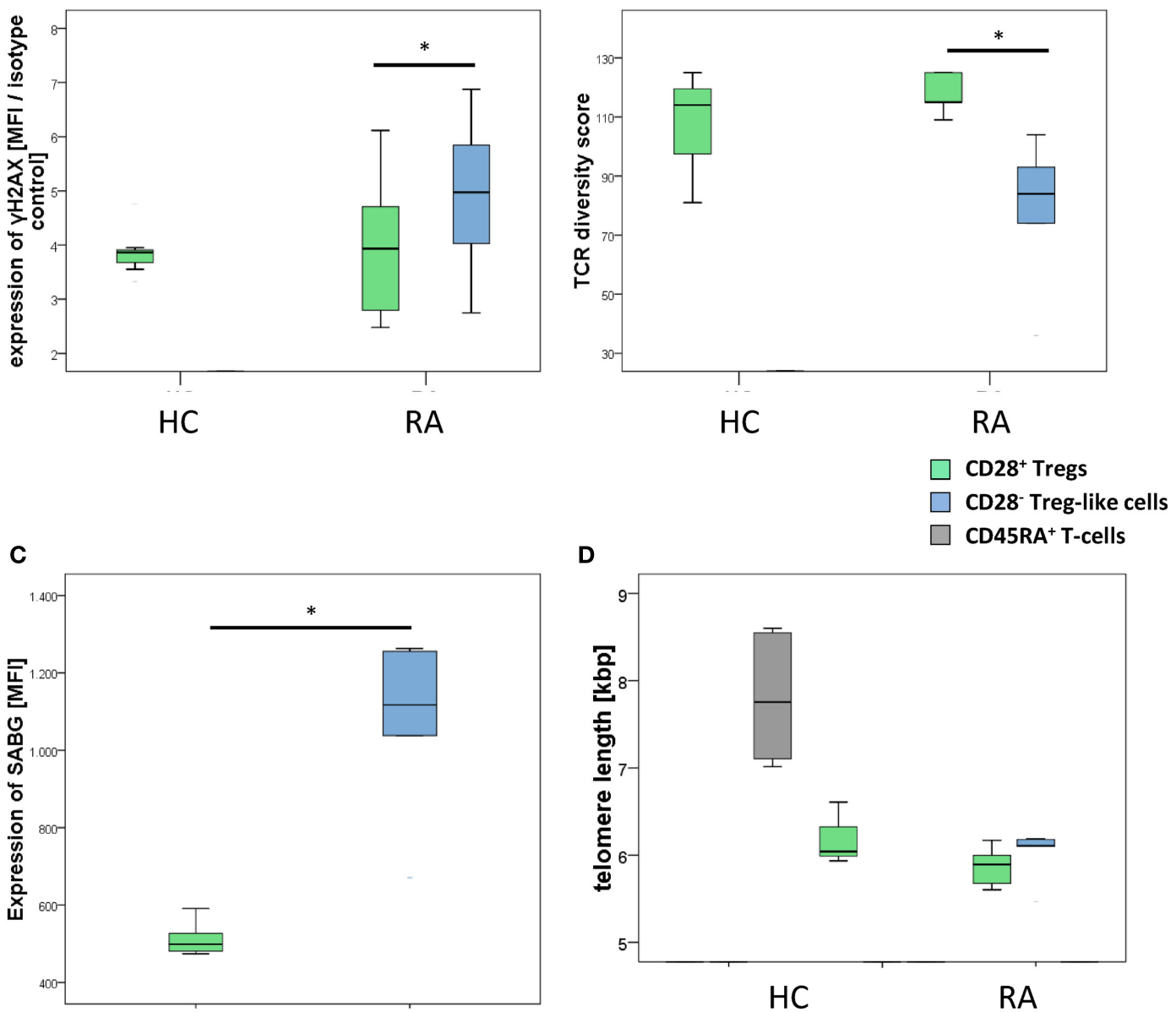

D

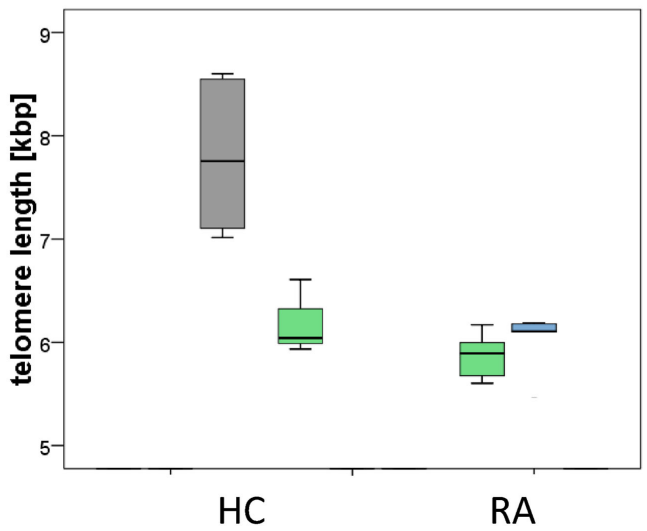

FIGURE 3 | CD28- regulatory T-cells (Tregs)-like cells show evidence of advanced replicative senescence. Graphs show (A) expression of $\gamma \mathrm{H} 2 \mathrm{AX}$, (B) T-cell receptor diversity, (C) expression of senescence-associated $\beta$-galactosidase (SABG), and (D) telomere lengths of CD28+ Tregs (green), CD28- Treg-like cells (blue), and naive CD45RA+ T-cells (gray). Mann-Whitney $U$ test was used to assess differences between groups. ${ }^{\star} p<0.05 ; n=5$.

variables, or treatment (Figures S1B,C in Supplementary Material and data not shown).

\section{CD28- Treg-Like Cells Can Be Generated In Vitro}

Previous studies reported that the downregulation of CD28 on T-cells is driven by pro-inflammatory signals including TNF- $\alpha$ or IL-15, which are also highly expressed in RA patients $(34,35)$. To test if these agents mediate the generation of CD28- Treg-like cells in vitro, we isolated $\mathrm{CD} 4{ }^{+} \mathrm{CD} 25^{\text {high }} \mathrm{CD} 127^{\mathrm{dim} /-}$ Tregs from healthy individuals and cultured them in the presence or absence of IL-15 or TNF- $\alpha$. We observed a significant decrease of CD28 on Tregs stimulated with TNF- $\alpha$ [3,295 (1,293-16,853)] compared to mock stimulation $[5,628.5(1,782-16,559) ; p=0.025$, Figure 4A]. A decrease of CD28 was also observed following incubation with IL-15. This difference, however, did not reach statistical significance $[4,483(713-15,309) ; p=0.138]$. Moreover, the reduced expression of CD28 was robust following elongated stimulation with TNF- $\alpha$ but not IL-15 (Figure 4B). Expression of CD25, CD127, and FoxP3 was not different following either way of stimulation and remained in Treg-specific expression levels (Figure 4C).

\section{CD28- Treg-Like Cells Produce High Levels of Pro- and Anti-inflammatory Cytokines}

Next, we examined the cytokine profile of CD28- Treg-like cells from RA patients. CD28 ${ }^{+}$Tregs are known to produce high levels of IL-10, which is one way how they inhibit effector cells (36). CD28- non-Tregs acquire a senescence-associated secretory phenotype, which is characterized by the predominate release of Th1 cytokines such as TNF- $\alpha$ and IFN- $\gamma$ (37).

CD28- Treg-like cells yielded a more pronounced production of IL-10 than CD28+ Tregs following stimulation with anti-CD3 [4\% (1.5-13.1) of CD28- Treg-like cells vs. $0.55 \%(0.3-1.6)$ of CD28 ${ }^{+}$Tregs were positive for IL-10; $p=0.005$, Table 1]. At 

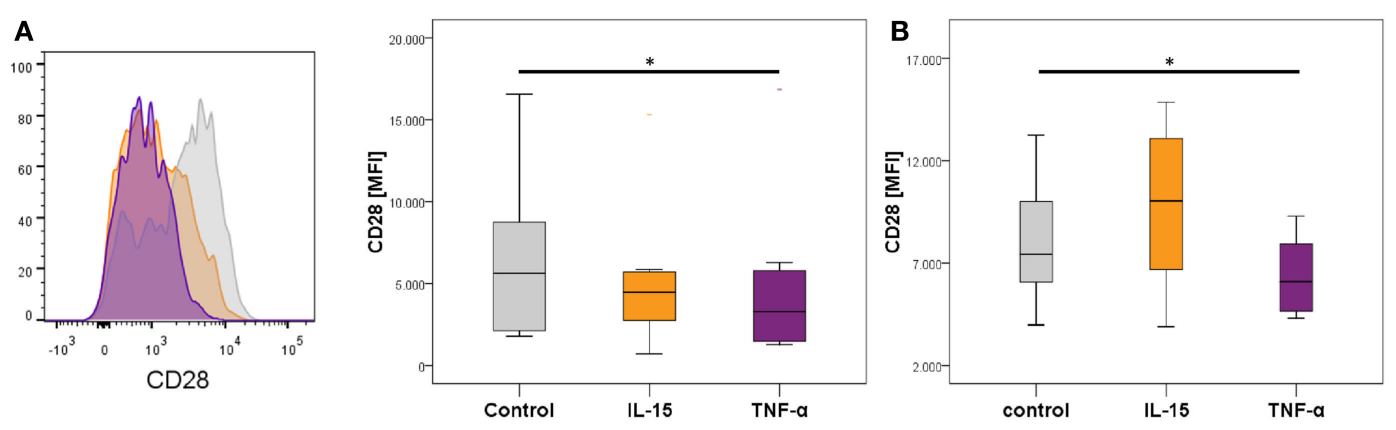

C
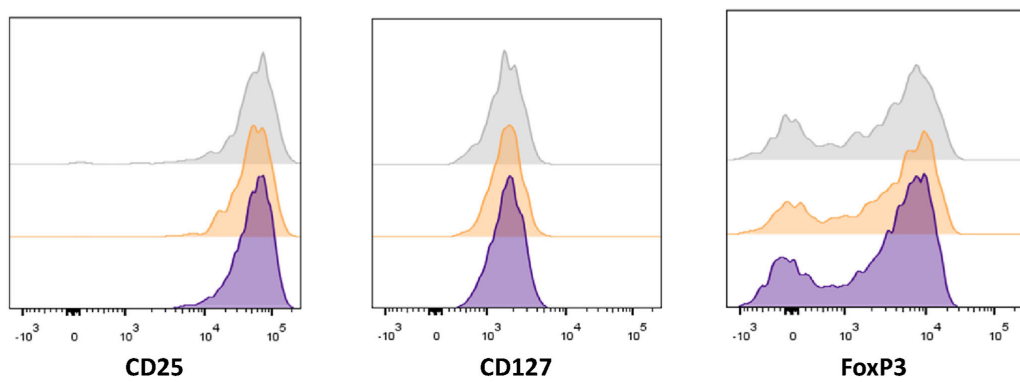

$\square$ control

$\square$ IL-15

$\square$ TNF- $\alpha$

FIGURE 4 | In vitro downregulation of CD28 in regulatory T-cells (Tregs) in the presence of TNF- $\alpha$. Graphs show (A) representative histograms showing CD28 expression of control Tregs (gray), following IL-15 stimulation (orange), and following TNF- $\alpha$ stimulation (violet), and box plots show median expression of CD28 (MFI) in Tregs of eight healthy individuals after the first expansion phase, (B) the second expansion phase, respectively; and (C) representative histograms of CD25, CD127, and FoxP3 expression. Mann-Whitney $U$ test was used to assess differences between groups. ${ }^{*} p<0.05$.

TABLE 1 | Cytokine production of CD28+ regulatory T-cells (Tregs) as well as CD28- Treg-like cells following stimulation in vitro.

\begin{tabular}{|c|c|c|c|c|c|}
\hline & $\%$ of CD28- Treg-like cells & $\%$ of CD28+ Tregs & $p$-Value ${ }^{a}$ & $\%$ of conv.CD28- T-cells & $p$-Value ${ }^{b}$ \\
\hline IL-2 & $15.45(5.1-31.1)$ & $4.55(1.1-12)$ & 0.005 & $8.8(3.6-35.6)$ & 0.114 \\
\hline IL-4 & $4.3(1.2-7.9)$ & $0.3(0.1-0.8)$ & 0.005 & $3.75(1.3-11.5)$ & 0.005 \\
\hline IL-10 & $4(1.5-13.1)$ & $0.55(0.3-1.6)$ & 0.005 & $4.15(0.5-13.4)$ & 0.594 \\
\hline $\mathrm{IL}-17$ & $4.9(1.5-14.6)$ & $0.7(0.2-1.7)$ & 0.005 & $4.05(1.6-9.7)$ & 0.203 \\
\hline TNF- $\alpha$ & $18(5.7-34.9)$ & $11.5(4.8-18.3)$ & 0.005 & $13.6(3.4-37)$ & 0.074 \\
\hline $\mathrm{IFN}-\gamma$ & $16.6(4.3-40.4)$ & $6.8(2.4-16.1)$ & 0.005 & $10.05(2.8-36.4)$ & 0.022 \\
\hline
\end{tabular}

${ }^{\mathrm{a}} \mathrm{CD} 28^{-}$-Treg-like cells vs. CD28+ Tregs.

${ }^{b} \mathrm{CD} 28^{-}$Treg-like cells vs. conv.CD28- T-cells.

the same time, however, cytokines characteristic for Th1 (IL-2, TNF- $\alpha$, and IFN- $\gamma$ ), Th2 (IL-4), and Th17 lineages (IL-17) were also more frequently produced by CD28- Treg-like cells compared to CD28 $8^{+}$Tregs (all $p=0.005$ ). The largest difference was observed concerning the production of IL-4 (14-fold).

Conventional senescent $\mathrm{CD}^{+}$T-cells produced lower amounts of IL- 4 and IFN- $\gamma$ than CD28- Treg-like cells, however, no difference was found regarding the production of IL-10. For details see Table 1 .

\section{CD28- Treg-Like Cells Are Less Suppressive than CD28+ Tregs}

The suppression of effector T-cells is a defining feature of regulatory cells. Tregs from mice with a conditional knockout for CD28 are non-suppressive, and in RA patients, Treg function has been reported (at least by some authors) to be defective $(5,19)$. Therefore, we studied the ability of CD28- Treg-like cells to suppress the proliferation of non-Tregs. As depicted in Figure 5A, the suppressive function of CD28- Treg-like cells from RA patients was compromised compared to that of CD28 ${ }^{+}$ Tregs [median reduction of proliferation of stimulated non-Tregs: $-2.2 \%(-8.7 .1$ to 77.7$)$ vs. $32.7 \%(-0.4$ to 77.9$) ; p=0.008]$.

Given that TNF- $\alpha$ and IFN- $\gamma$ were shown to interfere with Treg function in vitro and that $\mathrm{CD} 28^{-}$Treg-like cells produced high levels of these cytokines $(38,39)$, we tested whether the suppressive capacity of CD28- Treg-like cells was restored by the blockade of TNF- $\alpha$ or IFN- $\gamma$. The addition of neutralizing antibodies had no effect on the suppressive function of CD28Treg-like cells or CD28+ Tregs (Figures 5B,C).

\section{CD28- Treg-Like Cells Are Prone to Apoptosis}

Regulatory T-cells from CD28- deficient mice have a pronounced proliferative/survival disadvantage (19). Therefore, 


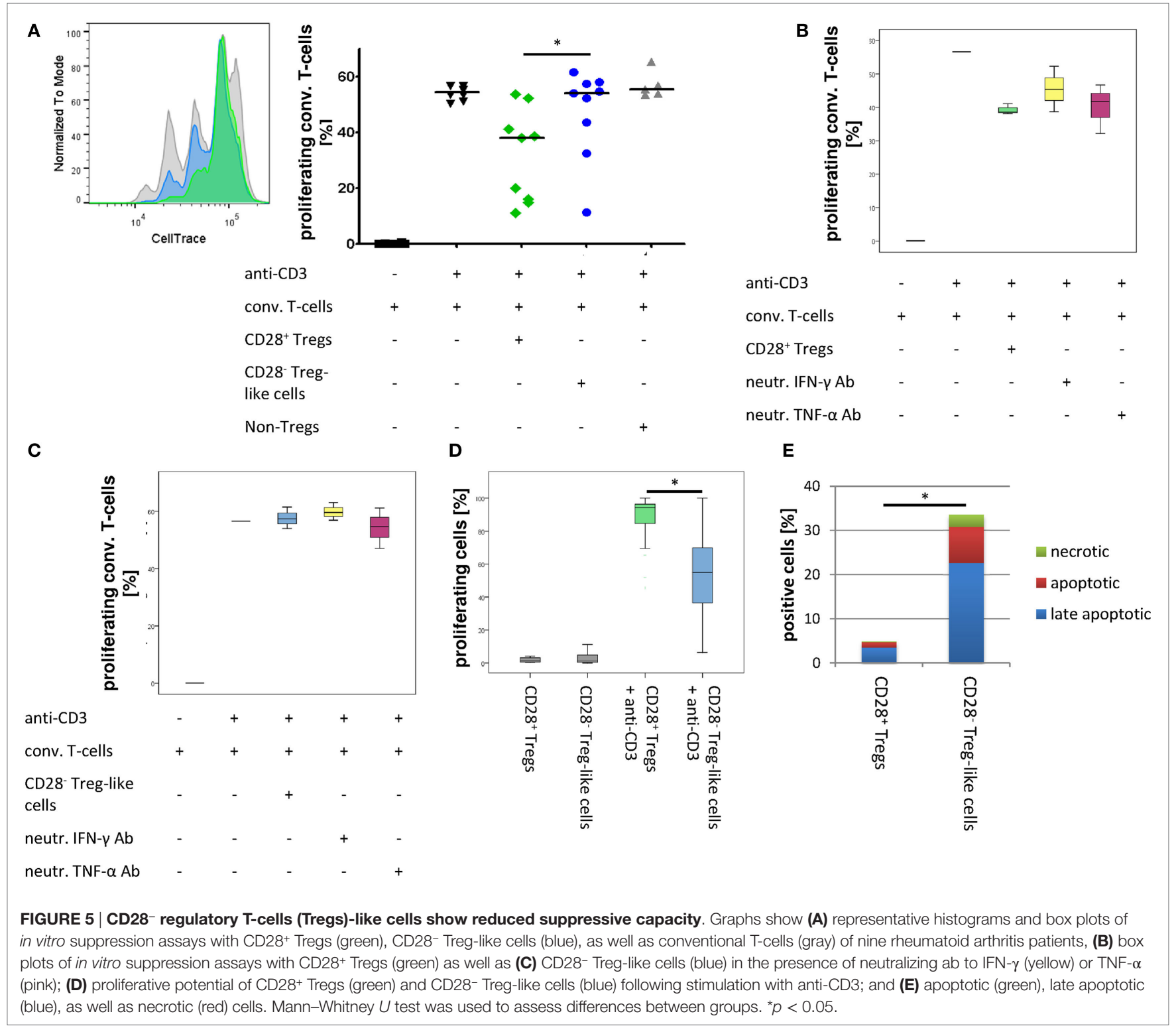

we analyzed the proliferative capacity and apoptosis induction of CD28- Treg-like cells. Upon stimulation with anti-CD3, we observed a lower rate of cell division of CD28- Treg-like cells compared to CD28+ Tregs [53.1\% CFSE ${ }^{\text {high }}$ (range 14.5-93.6) vs. $5.4 \%$ (0.9-30.6), respectively; $p=0.008$; Figure 5D]. In addition, we performed Annexin $\mathrm{V}$ staining assays in order to analyze apoptosis induction this subset. In the CD28- Treg-like subset, increased frequencies of early apoptotic [7\% (range 2-25.7) vs. $1 \%(0.5-2.5) ; p=0.005]$, necrotic $[1.9 \%(0-9.2)$ vs. $0.2 \%$ $(0.1-0.6) ; p=0.011]$, and late apoptotic cells [17.1\% (7.5-51.7) vs. $2.6 \%(1.3-8.4) ; p=0.005]$ were observed upon stimulation with anti-CD3 compared to the CD28 ${ }^{+}$Treg population. Overall, more than $30 \%$ of $\mathrm{CD} 28^{-}$Treg-like cells were apoptotic or necrotic upon activation compared to only $5 \%$ of CD $28^{+}$Tregs (Figure 5E).

\section{DISCUSSION}

In the present study, we describe the novel $\mathrm{CD} 4{ }^{+} \mathrm{CD} 28^{-} \mathrm{FoxP} 3^{+}$ T-cell subset. These cells reveal a phenotype compatible with senescent Tregs, have a reduced suppressive capacity compared to conventional $\mathrm{CD}^{+} \mathrm{CD}^{+} 8^{+} \mathrm{FoxP}^{+}$Tregs, show an increased production of pro- and anti-inflammatory cytokines, and display a high apoptosis rate. CD28- Treg-like cells can be generated in vitro upon stimulation with TNF- $\alpha$ in vitro, and they are found in RA patients in peripheral blood and at sites of inflammation in vivo.

The increment of $\mathrm{CD}^{+} \mathrm{CD} 28^{-}{ }^{-}$FoxP3 $3^{+} \mathrm{T}$-cells in RA patients compared to HC was modest, albeit some individuals showed remarkable frequencies of this cell subset (with a maximum of $19.2 \%$ of all CD $4^{+}$T-cells). Given that Treg frequencies account 
for only $\sim 5 \%$ of the total $\mathrm{CD} 4^{+} \mathrm{T}$-cell population, even small changes in the composition of this subset might lead to major changes in the immune response, particularly in cases where the immune system is disturbed already, such as in RA. CD28Treg-like cells only weakly suppressed effector T-cells in vitro and released pro- as well as anti-inflammatory cytokines. Given that the ability to suppress effector cells is the most robust definition of Treg function, the question arises, whether CD28- Treg-like cells still can be deemed as a regulatory subset. A major argument in favor of their regulatory origin is the expression of the transcription factor FoxP3. FoxP3 is essential for Treg development and function (27), and previous studies demonstrated that ectopic expression of FoxP3 in effector T-cells by retroviral gene transfer is sufficient to induce a Treg-like phenotype and function (40, 41). Besides, CD28- Treg-like cells had strongly upregulated inhibitory surface molecules such as PD-1 and CTLA-4 and produced the immunosuppressive cytokine IL-10 (even more than CD28+ Tregs).

The most plausible alternative interpretation of our findings is that $\mathrm{CD}^{+} \mathrm{CD}_{28}{ }^{-} \mathrm{FoxP}^{+}{ }^{+} \mathrm{T}$-cells are senescent non-Tregs that have transiently upregulated FoxP3 upon stimulation. $\mathrm{CD} 4^{+} \mathrm{CD} 28^{-}{ }^{-}$oxP $3{ }^{+} \mathrm{T}$-cells, however, were not only observed in RA patients with active disease but also in those in remission, and it is unlikely that $\mathrm{CD} 4^{+} \mathrm{CD} 28^{-}$T-cells are continuously stimulated in patients where all other disease activity parameters are low. In addition, transient FoxP3 expression has been reported for naïve T-cells only, whereas memory and effector T-cells (which CD28- T-cells belong to) seem not to upregulate this factor (42).

CD28- Treg-like cells described in the present study are similar to Tregs identified in a mouse model with a conditional knock-out for CD28 (19). These animals suffer from severe autoimmunity due to defective Tregs, which are unable to suppress inflammation. Specifically, Tregs from the CD28 knockout mouse model yielded a similar phenotype to human CD28- Treg-like cells such as the loss of CCR6 or the reduced expression of CD25, and an elevated production of IFN- $\gamma$. CCR6 is required for homing of Tregs to inflammatory sites (24), and Tregs of CD28- deficient mice were virtually absent in inflamed skin lesions (43). In the synovial fluid of RA patients, CD28- Treg-like cell levels were increased relative to circulation; however, this does not exclude a homing defect of CD28- Treglike cells because they could have been generated locally under the influence of pro-inflammatory cytokines such as TNF- $\alpha$ with subsequent efflux to periphery. Our in vitro experiments demonstrated that TNF- $\alpha$ downregulates CD28 on Tregs and TNF- $\alpha$ levels are known to be high in inflamed joints of RA patients (44). Nevertheless, TNF- $\alpha$-induced CD28- Tregs do not completely reflect CD28- Treg-like cells described in vivo since expression levels of CD25 and CD127 were unaltered in in vitro stimulated cells. These differences are potentially caused by the length of stimulation and/or the presence of additional cytokines in vivo.

CD28- Treg-like cells from RA patients had a clear survival disadvantage compared to $\mathrm{CD} 28^{+}$Tregs, which is again in line with the observations from the CD28 conditional knockout model (19). CD28- Treg-like cells yielding a lower proliferative capacity plus a higher apoptosis rate are presumably functionally unable to halt autoimmune effector cells. Besides, CD28- Treglike cells from RA patients released several pro-inflammatory cytokines such as IFN- $\gamma$ or TNF- $\alpha$ which might further promote the inflammatory process (38). Previous studies reported that treatment of RA patients with TNF $\alpha$ blockers restores Treg function $(5,45)$, whereas in our group, no association of antiTNF therapy (or any other clinical variable except for age) with CD28- Treg-like cell prevalence or function was found. This might be explained by the clinical heterogeneity of our cohort and the small sample size that lacked the power to elucidate the relation between different clinical phenotypes, therapies and CD28- Treg-like cells. Larger studies are certainly needed to clarify this issue.

CD28- ${ }^{-}$Treg-like cells from RA patients expressed lower levels of CD25 compared to Tregs, which might have had an impact on their regulatory function. CD25 has been reported to operationally differentiate naturally present, autoimmunepreventive Tregs from other T-cells and therefore mediate immunosuppression (27). On the other hand, functional Treg subsets with a lower expression of CD25 have been reported, as well: a proportion of Tregs from aged mice, for example, showed decreased expression of CD25 $(46,47)$. These CD25 low Tregs occurred predominantly in the spleen (48) but had comparable functional properties to CD $25^{+}$Tregs. Similarly, a $\mathrm{CD} 4{ }^{+} \mathrm{CD} 25^{\text {low }} \mathrm{FoxP} 3^{+}$Treg population has been observed in SLE patients, and given that SLE patients have a prematurely aged immune system with accumulation of CD28- ${ }^{-}$-cells (49), it is conceivable that (at least part of) this $\mathrm{CD} 4^{+} \mathrm{CD} 25^{\text {low }} \mathrm{FoxP} 3^{+}$ Treg population was $\mathrm{CD}_{2} 8^{-}$. A more recent study reported enhanced frequencies of CD25-FoxP $3^{+}$T-cells in RA patients and a negative correlation of this subset with disease activity (50). Unfortunately, no functional experiments were conducted with these cells thus not allowing to elucidate the overlaps and differences between these cell populations and clearly link CD $4^{+}$ $\mathrm{CD}^{2} 5^{\text {low }} \mathrm{FoxP} 3^{+}$Tregs with CD28- ${ }^{-}$Treg-like cells.

The most important limitation of this study is the uncertain identification of human Tregs by flow cytometry. No combination of surface molecules enables specific identification and isolation of Tregs. The transcription factors FoxP3 is still deemed as the most specific Treg marker; however, activated naive T-cells without suppressive function may transiently express this factor, as well. Second, RA is a heterogeneous disease with various clinical phenotypes. It is likely that the pathophysiology differs between various clinical subsets, and ideally, experiments would have been performed in different groups, stratified by their clinical phenotype. Third, we were unable to clarify whether CD28- Treg-like cells occur before the clinical onset of RA (thus presumably contributing directly to the pathogenesis of the disease) or whether they occur later in course, secondary to chronic inflammation. Previous studies investigating healthy individuals with a genetic risk for RA concluded that early T-cell senescence, which might also involve the Treg lineage, is in part genetically determined and might well occur before the clinical onset of disease (51). 
In conclusion, we describe a novel T-cell subset combining a regulatory phenotype with signs of $\mathrm{T}$-cell senescence. This novel subset might represent a late developmental stage of Tregs $\left(\mathrm{CD} 4^{+} \mathrm{CD} 28^{-}{ }^{-}\right.$oxP $3^{+}$T-cell). CD28- ${ }^{-}$Treg-like cells revealed a reduced suppression of effector cells, produced pro- and anti-inflammatory cytokines, and had a survival disadvantage compared to $\mathrm{CD} 28^{+}$Tregs. The CD28- Treglike cell population might thus contribute to the pathogenic immune response in RA.

\section{AUTHOR CONTRIBUTIONS}

JF, WG, MS, and CDe designed the research study. JF, AR, RH, AF, and CS conducted the experiments and acquired data. JF, CDu, WS, MS, and CDe analyzed data. WS and WG provided reagents. JF, MS, and CDe wrote the manuscript.

\section{REFERENCES}

1. Fessler J, Felber A, Duftner C, Dejaco C. Therapeutic potential of regulatory T cells in autoimmune disorders. BioDrugs (2013) 27:281-91. doi:10.1007/ s40259-013-0026-5

2. Lawson CA, Brown AK, Bejarano V, Douglas SH, Burgoyne $\mathrm{CH}$, Greenstein AS, et al. Early rheumatoid arthritis is associated with a deficit in the $\mathrm{CD} 4+\mathrm{CD} 25$ high regulatory $\mathrm{T}$ cell population in peripheral blood. Rheumatology (Oxford) (2006) 45:1210-7. doi:10.1093/rheumatology/kel089

3. van Amelsfort JM, Jacobs KM, Bijlsma JW, Lafeber FP, Taams LS. CD4(+) $\mathrm{CD} 25(+)$ regulatory $\mathrm{T}$ cells in rheumatoid arthritis: differences in the presence, phenotype, and function between peripheral blood and synovial fluid. Arthritis Rheum (2004) 50:2775-85. doi:10.1002/art.20499

4. Han GM, O'Neil-Andersen NJ, Zurier RB, Lawrence DA. CD4+CD25high $\mathrm{T}$ cell numbers are enriched in the peripheral blood of patients with rheumatoid arthritis. Cell Immunol (2008) 253:92-101. doi:10.1016/j.cellimm.2008. 05.007

5. Ehrenstein MR, Evans JG, Singh A, Moore S, Warnes G, Isenberg DA, et al. Compromised function of regulatory $\mathrm{T}$ cells in rheumatoid arthritis and reversal by anti-TNFalpha therapy. J Exp Med (2004) 200:277-85. doi:10.1084/ jem.20040165

6. Nie H, Zheng Y, Li R, Guo TB, He D, Fang L, et al. Phosphorylation of FOXP3 controls regulatory $\mathrm{T}$ cell function and is inhibited by TNF- $\alpha$ in rheumatoid arthritis. Nat Med (2013) 19:322-8. doi:10.1038/nm.3085

7. Walter GJ, Fleskens V, Frederiksen KS, Rajasekhar M, Menon B, Gerwien $\mathrm{JG}$, et al. Phenotypic, functional, and gene expression profiling of peripheral CD45RA+ and CD45RO+ CD4+CD25+CD127(low) treg cells in patients with chronic rheumatoid arthritis. Arthritis Rheumatol (2016) 68:103-16. doi:10.1002/art.39408

8. Wing K, Ekmark A, Karlsson H, Rudin A, Suri-Payer E. Characterization of human CD25+ CD4+ T cells in thymus, cord and adult blood. Immunology (2002) 106:190-9. doi:10.1046/j.1365-2567.2002.01412.x

9. Takahata Y, Nomura A, Takada H, Ohga S, Furuno K, Hikino S, et al. CD25+CD4+ T cells in human cord blood: an immunoregulatory subset with naive phenotype and specific expression of forkhead box p3 (Foxp3) gene. Exp Hematol (2004) 32:622-9. doi:10.1016/j.exphem.2004.03.012

10. Seddiki N, Santner-Nanan B, Tangye SG, Alexander SI, Solomon M, Lee S, et al. Persistence of naive CD45RA+ regulatory $\mathrm{T}$ cells in adult life. Blood (2006) 107:2830-8. doi:10.1182/blood-2005-06-2403

11. Steinmann GG, Klaus B, Muller-Hermelink HK. The involution of the ageing human thymic epithelium is independent of puberty. A morphometric study. Scand J Immunol (1985) 22:563-75. doi:10.1111/j.1365-3083.1985. tb01916.x

12. Mackall CL, Bare CV, Granger LA, Sharrow SO, Titus JA, Gress RE. Thymicindependent $\mathrm{T}$ cell regeneration occurs via antigen-driven expansion of peripheral $\mathrm{T}$ cells resulting in a repertoire that is limited in diversity and prone to skewing. J Immunol (1996) 156:4609-16.

\section{ACKNOWLEDGMENTS}

The authors thank I. Holzer, D. Peischler, and J. Weber for their assistance with cell culture experiments and FACS.

\section{SUPPLEMENTARY MATERIAL}

The Supplementary Material for this article can be found online at http://journal.frontiersin.org/article/10.3389/fimmu. 2017.00300/full\#supplementary-material.

\section{FIGURE S1 | CD28- Treg-like cells are not correlated with disease} parameters in RA. Graphs (A) correlation of CD28- Treg-like cells with age in $\mathrm{HC}$ (blue) and RA patients (red); (B) correlation of CD28- Treg-like cells with disease duration and (C) correlation of CD28- Treg-like cells with DAS28 in RA patients. Correlation between variables was evaluated by the Spearman's rank correlation coefficient.

13. Valmori D, Merlo A, Souleimanian NE, Hesdorffer CS, Ayyoub M. A peripheral circulating compartment of natural naive CD4 Tregs. J Clin Invest (2005) 115:1953-62. doi:10.1172/JCI23963

14. Goronzy JJ, Matteson EL, Fulbright JW, Warrington KJ, Chang-Miller A, Hunder GG, et al. Prognostic markers of radiographic progression in early rheumatoid arthritis. Arthritis Rheum (2004) 50:43-54. doi:10.1002/art.11445

15. Warrington KJ, Takemura S, Goronzy JJ, Weyand CM. CD4+, CD28- $\mathrm{T}$ cells in rheumatoid arthritis patients combine features of the innate and adaptive immune systems. Arthritis Rheum (2001) 44:13-20. doi:10.1002/1529-0131(200101)44:1<13::AID-ANR3>3.0.CO;2-6

16. Solomon DH, Karlson EW, Rimm EB, Cannuscio CC, Mandl LA, Manson JE, et al. Cardiovascular morbidity and mortality in women diagnosed with rheumatoid arthritis. Circulation (2003) 107:1303-7. doi:10.1161/ 01.CIR.0000054612.26458.B2

17. Koetz K, Bryl E, Spickschen K, O’Fallon WM, Goronzy JJ, Weyand CM. T cell homeostasis in patients with rheumatoid arthritis. Proc Natl Acad Sci U S A (2000) 97:9203-8. doi:10.1073/pnas.97.16.9203

18. Zhang X, Nakajima T, Goronzy JJ, Weyand CM. Tissue trafficking patterns of effector memory CD4+ T cells in rheumatoid arthritis. Arthritis Rheum (2005) 52:3839-49. doi:10.1002/art.21482

19. Zhang R, Huynh A, Whitcher G, Chang J, Maltzman JS, Turka LA. An obligate cell-intrinsic function for CD28 in Tregs. J Clin Invest (2013) 123:580-93. doi:10.1172/JCI65013

20. van der Linden S, Valkenburg HA, Cats A. Evaluation of diagnostic criteria for ankylosing spondylitis. A proposal for modification of the New York criteria. Arthritis Rheum (1984) 27:361-8. doi:10.1002/art.1780270401

21. Smolen JS, Breedveld FC, Schiff MH, Kalden JR, Emery P, Eberl G, et al. A simplified disease activity index for rheumatoid arthritis for use in clinical practice. Rheumatology (Oxford) (2003) 42:244-57. doi:10.1093/ rheumatology/keg072

22. van Gestel AM, Haagsma CJ, van Riel PL. Validation of rheumatoid arthritis improvement criteria that include simplified joint counts. Arthritis Rheum (1998) 41:1845-50. doi:10.1002/1529-0131(199810)41: 10<1845:AID-ART17>3.0.CO;2-K

23. Hingorani R, Monteiro J, Furie R, Chartash E, Navarrete C, Pergolizzi R, et al. Oligoclonality of $\mathrm{V}$ beta 3 TCR chains in the CD8+ T cell population of rheumatoid arthritis patients. J Immunol (1996) 156:852-8.

24. Fessler J, Raicht A, Husic R, Ficjan A, Duftner C, Schwinger W, et al. Premature senescence of T-cell subsets in axial spondyloarthritis. Ann Rheum Dis (2016) 75:748-54. doi:10.1136/annrheumdis-2014-206119

25. Yang J, Fan H, Hao J, Ren Y, Chen L, Li G, et al. Amelioration of acute graftversus-host disease by adoptive transfer of ex vivo expanded human cord blood CD4+CD25+ forkhead box protein 3+ regulatory $\mathrm{T}$ cells is associated with the polarization of Treg/Th17 balance in a mouse model. Transfusion (2012) 52:1333-47. doi:10.1111/j.1537-2995.2011.03448.x

26. Shevach EM. Regulatory/suppressor T cells in health and disease. Arthritis Rheum (2004) 50:2721-4. doi:10.1002/art.20500 
27. Sakaguchi S. Naturally arising Foxp3-expressing CD25+CD4+ regulatory $\mathrm{T}$ cells in immunological tolerance to self and non-self. Nat Immunol (2005) 6:345-52. doi:10.1038/ni1178

28. Yamazaki T, Yang XO, Chung Y, Fukunaga A, Nurieva R, Pappu B, et al. CCR6 regulates the migration of inflammatory and regulatory $\mathrm{T}$ cells. J Immunol (2008) 181:8391-401. doi:10.4049/jimmunol.181.12.8391

29. Sedelnikova OA, Horikawa I, Zimonjic DB, Popescu NC, Bonner WM, Barrett JC. Senescing human cells and ageing mice accumulate DNA lesions with unrepairable double-strand breaks. Nat Cell Biol (2004) 6:168-70. doi:10.1038/ncb1095

30. Naylor K, Li G, Vallejo AN, Lee WW, Koetz K, Bryl E, et al. The influence of age on T cell generation and TCR diversity. J Immunol (2005) 174:7446-52. doi:10.4049/jimmunol.174.11.7446

31. Dimri GP, Lee X, Basile G, Acosta M, Scott G, Roskelley C, et al. A biomarker that identifies senescent human cells in culture and in aging skin in vivo. Proc Natl Acad Sci U S A (1995) 92:9363-7. doi:10.1073/pnas.92.20.9363

32. Hohensinner PJ, Goronzy JJ, Weyand CM. Telomere dysfunction, autoimmunity and aging. Aging Dis (2011) 2:524-37.

33. Aletaha D, Smolen J. The simplified disease activity index (SDAI) and the clinical disease activity index (CDAI): a review of their usefulness and validity in rheumatoid arthritis. Clin Exp Rheumatol (2005) 23:S100-8.

34. Bryl E, Vallejo AN, Weyand CM, Goronzy JJ. Down-regulation of CD28 expression by TNF-alpha. J Immunol (2001) 167:3231-8. doi:10.4049/ jimmunol.167.6.3231

35. Yamada H, Kaibara N, Okano S, Maeda T, Shuto T, Nakashima Y, et al. Interleukin-15 selectively expands CD57+ CD28- CD4+ T cells, which are increased in active rheumatoid arthritis. Clin Immunol (2007) 124:328-35. doi:10.1016/j.clim.2007.06.001

36. Murai M, Turovskaya O, Kim G, Madan R, Karp CL, Cheroutre H, et al. Interleukin 10 acts on regulatory $\mathrm{T}$ cells to maintain expression of the transcription factor Foxp3 and suppressive function in mice with colitis. Nat Immunol (2009) 10:1178-84. doi:10.1038/ni.1791

37. Tchkonia T, Zhu Y, van Deursen J, Campisi J, Kirkland JL. Cellular senescence and the senescent secretory phenotype: therapeutic opportunities. JClin Invest (2013) 123:966-72. doi:10.1172/JCI64098

38. Valencia X, Stephens G, Goldbach-Mansky R, Wilson M, Shevach EM, Lipsky PE. TNF downmodulates the function of human CD4+CD25hi T-regulatory cells. Blood (2006) 108:253-61. doi:10.1182/blood-2005-11-4567

39. Hernandez AL, Kitz A, Wu C, Lowther DE, Rodriguez DM, Vudattu N, et al. Sodium chloride inhibits the suppressive function of FOXP3+ regulatory T cells. J Clin Invest (2015) 125:4212-22. doi:10.1172/JCI81151

40. Bennett CL, Christie J, Ramsdell F, Brunkow ME, Ferguson PJ, Whitesell L, et al. The immune dysregulation, polyendocrinopathy, enteropathy, X-linked syndrome (IPEX) is caused by mutations of FOXP3. Nat Genet (2001) 27:20-1. doi:10.1038/83713

41. Fontenot JD, Gavin MA, Rudensky AY. Foxp3 programs the development and function of CD4+CD25+ regulatory T cells. Nat Immunol (2003) 4:330-6. doi:10.1038/ni904

42. Tran DQ, Ramsey H, Shevach EM. Induction of FOXP3 expression in naive human $\mathrm{CD} 4+\mathrm{FOXP} 3 \mathrm{~T}$ cells by $\mathrm{T}$-cell receptor stimulation is transforming growth factor-beta dependent but does not confer a regulatory phenotype. Blood (2007) 110:2983-90. doi:10.1182/blood-2007-06094656

43. Zhang R, Borges CM, Fan MY, Harris JE, Turka LA. Requirement for CD28 in effector regulatory $\mathrm{T}$ cell differentiation, CCR6 induction, and skin homing J Immunol (2015) 195:4154-61. doi:10.4049/jimmunol.1500945

44. Saxne T, Palladino MA, Heinegård D, Talal N, Wollheim FA. Detection of tumor necrosis factor alpha but not tumor necrosis factor beta in rheumatoid arthritis synovial fluid and serum. Arthritis Rheum (1988) 31:1041-5. doi:10.1002/art.1780310816

45. McGovern JL, Nguyen DX, Notley CA, Mauri C, Isenberg DA, Ehrenstein MR. Th17 cells are restrained by Treg cells via the inhibition of interleukin- 6 in patients with rheumatoid arthritis responding to anti-tumor necrosis factor antibody therapy. Arthritis Rheum (2012) 64:3129-38. doi:10.1002/ art. 34565

46. Chougnet CA, Tripathi P, Lages CS, Raynor J, Sholl A, Fink P, et al. A major role for Bim in regulatory T cell homeostasis. J Immunol (2011) 186:156-63. doi:10.4049/jimmunol.1001505

47. Nishioka T, Shimizu J, Iida R, Yamazaki S, Sakaguchi S. CD4+CD25+Foxp3+ $\mathrm{T}$ cells and CD4+CD25-Foxp3+ T cells in aged mice. JImmunol (2006) 176:6586-93. doi:10.4049/jimmunol.176.11.6586

48. Lages CS, Suffia I, Velilla PA, Huang B, Warshaw G, Hildeman DA, et al. Functional regulatory $\mathrm{T}$ cells accumulate in aged hosts and promote chronic infectious disease reactivation. J Immunol (2008) 181:1835-48. doi:10.4049/ jimmunol.181.3.1835

49. Bonelli M, Savitskaya A, Steiner CW, Rath E, Smolen JS, Scheinecker C. Phenotypic and functional analysis of CD4+ CD25- Foxp3+ T cells in patients with systemic lupus erythematosus. J Immunol (2009) 182:1689-95. doi:10.4049/jimmunol.182.3.1689

50. de Paz B, Prado C, Alperi-López M, Ballina-García FJ, Rodriguez-Carrio J, López P, et al. Effects of glucocorticoid treatment on CD25-FOXP3+ population and cytokine-producing cells in rheumatoid arthritis. Rheumatology (Oxford) (2012) 51:1198-207. doi:10.1093/rheumatology/kes039

51. Schonland SO, Lopez C, Widmann T, Zimmer J, Bryl E, Goronzy JJ, et al Premature telomeric loss in rheumatoid arthritis is genetically determined and involves both myeloid and lymphoid cell lineages. Proc Natl Acad Sci US A (2003) 100:13471-6. doi:10.1073/pnas.2233561100

Conflict of Interest Statement: The authors declare that the research was conducted in the absence of any commercial or financial relationships that could be construed as a potential conflict of interest.

Copyright (c) 2017 Fessler, Raicht, Husic, Ficjan, Schwarz, Duftner, Schwinger, Graninger, Stradner and Dejaco. This is an open-access article distributed under the terms of the Creative Commons Attribution License (CC BY). The use, distribution or reproduction in other forums is permitted, provided the original author(s) or licensor are credited and that the original publication in this journal is cited, in accordance with accepted academic practice. No use, distribution or reproduction is permitted which does not comply with these terms. 